\title{
Anti-Urolithiatic Effect of Pericampylus glaucus against Ethylene Glycol Induced Urolithiasis in Male Sprague Dawley Rats \\ (Kesan Anti-Urolitiatik Pericampylus glaucus terhadap Urolitiasis Teraruh Etilena Glikol dalam Tikus Jantan Sprague Dawley)
}

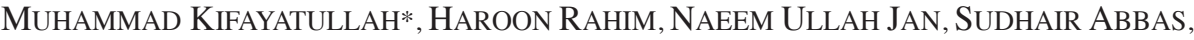 \\ MUHAMMAD SHAHID KHAN \& MUHAMMAD IKRAM
}

\begin{abstract}
Pericampylus glaucus is a common plant used traditionally for the remedies of urinary and kidney stones. Hence, present research was aimed to investigate the antiurolithiatic effect of ethanol extract of P. glaucus against ethylene glycol induced urolithiasis in male Sprague Dawley rats. The nephrolithiasis was induced by ethylene glycol $(0.75 \% \mathrm{v} / \mathrm{v})$ in drinking water over a period of 30 days. The animals were divided into normal, lithiatic and extract treated group that received ethanolic extract of P. glaucus at dose rate of 200 and $400 \mathrm{mg} / \mathrm{kg}$ (b.wt) by mouth. The calcium, phosphate, urine $\mathrm{pH}$, oxalate, magnesium in urine and histopathalogical examination of the kidney were observed. A significant $(\mathrm{p}<0.01)$ increased in the levels of phosphate, calcium, oxalate, and an imbalance in kidney with decreased magnesium excretion in urine were observed in ethylene glycol induced urolithiasis as compared to normal control. Treatment with ethanolic extract of P. glaucus at dose of 200 and $400 \mathrm{mg} / \mathrm{kg}(\mathrm{b} . \mathrm{wt})$ decreased significantly $(\mathrm{p}<0.01)$ the hyperoxaluria, calcium, phosphate, oxalate with significant $(\mathrm{p}<0.05)$ increased retention of urinary magnesium and improvement in the renal function as matched to lithiatic group. The histopathological examination showed the deposition of a large number of calcium oxalate crystal in lithiatic group while smaller depositions in $200 \mathrm{mg} / \mathrm{kg}$ (b.wt) extract treated group. The results confirmed the antiurolithiatic effect of $\mathrm{P}$. glaucus in male Sprague Dawley rats and validate its traditional uses against urinary stone.
\end{abstract}

Keywords: Anti-urolithiatic; ethylene glycol induced; hyperoxaluria; Pericampylus glaucus

\section{ABSTRAK}

Pericampylus glaucus adalah tumbuhan yang biasa digunakan secara tradisi untuk pemulihan kencing dan batu karang. Oleh itu, penyelidikan ini bertujuan untuk mengkaji kesan antiurolitiatik ekstrak etanol P. glaucus terhadap urolitiasis teraruh etilena glikol dalam tikus jantan Sprague Dawley. Nephrolithiasis telah diaruh etilena glikol $(0.75 \% \mathrm{v} / \mathrm{v})$ dalam air minuman selama 30 hari. Tikus tersebut dibahagikan kepada kumpulan normal, litiatik dan kumpulan terawat ekstrak yang mendapat ekstrak etanolik P. glaucus pada kadar dos 200 dan $400 \mathrm{mg} / \mathrm{kg}$ (b.wt) melalui mulut. Kalsium, fosfat, $\mathrm{pH}$ air kencing, oksalat, magnesium dalam air kencing dan pemeriksaan histopatologi buah pinggang telah dicerapkan. Peningkatan signifikan $(\mathrm{p}<0.01)$ tahap fosfat, kalsium, oksalat dan ketidakseimbangan pada buah pinggang dengan penurunan magnesium perkumuhan dalam air kencing dicerapkan dalam urolithiasis teraruh etilena glikol berbanding kawalan normal. Rawatan dengan ekstrak etanol P. glaucus pada 200 dan $400 \mathrm{mg} /$ kg (b.wt) menurunkan dengan ketara $(\mathrm{p}<0.01)$ hiperoksaluria, kalsium, fosfat, oksalat dengan peningkatan ketara $(\mathrm{p}<0.05)$ pengekalan kencing magnesium dan peningkatan fungsi buah pinggang agar sama dengan kumpulan litiatik Pemeriksaan histopatologi menunjukkan pemendapan sejumlah besar kristal oksalat kalsium dalam kumpulan litiatik manakala deposisi yang lebih kecil dalam ekstrak $200 \mathrm{mg} / \mathrm{kg}$ (b.wt) kumpulan terawat. Hasil mengesahkan kesan antiurolitiatik P. glaucus pada tikus jantan Sprague Dawley dan mengesahkan kegunaan secara tradisi terhadap batu karang.

Kata kunci: Anti urolitiatik; etilena glikol teraruh; hiperoksaluria; Pericampylus glaucus

\section{INTRODUCTION}

The development of stony concretions in body either in the urinary system or gall bladder are known as lithiasis. Nephrolithiasis and urolithiasis are the common types of lithiasis being claimed as of the main source of renal failure in human as reported in literature (Prasad \& Bharathi 2007). These types of lithiasis are present in $12 \%$ of worldwide population, affecting mostly male with recurrence rate are (70-80\%) as compared to female (47-60\%) (Awari et al. 2009; Choubey et al. 2010). Calcium oxalate contributes $75-90 \%$ of the total kidney stones followed by magnesium ammonium phosphate $10-15 \%$, cystine $0.5-1 \%$ and uric acid 3-10\% (Ashok \& Vishwanathswamy 2010). There is no proper treatment and physicians just medicate the pain 
until the stones get out their own as previously reported in research paper (Chitme et al. 2010). Lithotripsy and surgical procedures are also carried out but the risks factors associate with these therapy are not corrected until now (Betanabhatla et al. 2009). Furthermore, medical management of lithiasis involved surgical exclusion and extracorporeal shock lithotripsy techniques (Sathish et al. 2010). But, the side effects are linked with these therapeutic techniques. Therefore, there is an urge to find an alternative medicine from natural product with no side effect and maximum benefits (Betanabhatla et al. 2009). The plant 'Pericampylus glaucus' commonly known as 'Akkar chupping', which is traditionally used in the remedy of kidney stone and other variety of diseases as reported in literature (Kifayatullah et al.2017a). Despite of traditional use, plant was previously investigated scientifically against cancer cell (Zhao \& Cui 2009), followed by hepatitis B, C, AIDS (Yan et al. 2008), and diabetes (Kifayatullah \& Sengupta 2016). But, no scientific paper was reported on this plant for urolithiasis. Hence, the objective of the present research was to determine the antiurolithiatic effect of Pericampylus glaucus against ethylene glycol induced urolithiasis in male Sprague Dawley rats.

\section{MATERIALS AND METHODS}

\section{COLLECTION AND IDENTIFICATION OF PLANT MATERIAL}

The whole plant of Pericampylus glaucus was collected from Kampung Jeram Kedah, Negeri Sembilan, Malaysia in the month of June 2014 and was authenticated by Forest Research Institute Malaysia (FRIM) with voucher specimen herbarium number (FRIM/394/490/5/18(118), deposited to the Faculty of Pharmacy, Lincoln University College, Malaysia.

\section{CHEMICALS AND REAGENTS}

Chemicals used in this study were ethylene glycol (Sigma Aldrich Germany), chloroform (Riedel-DeHaen, Germany), formaldehyde 37\% solution (Merck Germany), xylene, ethanol (Merck, Germany), paraffin, adhesive material, potassium dihydrogen phosphate extra pure (Riedel-De- Haën, Germany), sodium dihydrogen phosphate (Merck, Germany).

\section{EQUIPMENTS}

Equipment used were Microscope labomed (USA), centrifuge rotofix 32 A (Hettich Zentrifugen). Digital weighing balance, TE214 (Sartorius Germany) and GE4101 (Sartorius Germany) capacity 0.1-4200 g, pH meter (pH720, WTw) and Microtome HM310 Sakura (Germany).

\section{EXPERIMENTAL DETAILS}

Thirty male Sprague-Dawley rats weighing between 100 and $110 \mathrm{~g}$ were used in this study, which were supplied from Institute for Medical Research, Pahang. The animals were kept in plastic cages and placed in animals holding facility centre of Lincoln University College where the standard laboratory condition $\left(26 \pm 2^{\circ} \mathrm{C}\right)$ with humidity $(50 \pm 4 \%)$ and the natural lighting $12 \mathrm{~h}$ light/12 h night were maintained. The study was conducted according to the standard guidelines for the animal's care, which was approved by the Animal Ethics Committee of Lincoln University College, Malaysia (LUC-AEC) with approval number PHARM/2013/MSM/02-AUGUST/11/ SEPTEMBER2014-AUGUST 2016. Standard pellet diet and water ad libitum were provided to animals during the whole experiment in accordance to the CPSCEA guidelines.

\section{EXTRACTION OF PLANT MATERIAL}

The leaves were dried in shade for 20 days and converted into coarse powder with the help of grinder. After converting into coarse powder, an amount of $500 \mathrm{~g}$ of powder was subjected to extraction by continuous hot extraction method using ethanol $(95 \%)$ as a solvent soxhlet in apparatus. The resultant ethanolic extract was then concentrated under reduced pressure $\left(40-45^{\circ} \mathrm{C}\right)$ in a rotary evaporator. The residue left in evaporator was kept in dedicator for further pharmacological activities (Yadav \& Agarwala 2011).

\section{PRELIMINARY PHYTOCHEMICAL SCREENING}

The presence of various phytochemicals in ethanol extract of Pericampylus glaucus was examined earlier by using different types of chemical identification tests that show the presence of alkaloids, saponins, reducing sugar, phenol, tannins, flavonoid, terpeniods and sterol except anthraquione and resins (Kifayatullah et al. 2017b), as reported previously in research paper.

\section{ACUTE TOXICITY STUDY}

OECD guideline 423 was followed for ethanol extract of Pericampylus glaucus on female Balb/c mice where the maximum single dose $2000 \mathrm{mg} / \mathrm{kg}$ (b.wt) by mouth was used. The administered dose was found safe and no mortality was observed in treated groups (Kifayatullah et al. 2015a). Therefore, $1 / 10^{\text {th }}$ of the highest dose 200 and $400 \mathrm{mg} / \mathrm{kg}$ (b.wt) was selected for investigation of antianti-urolithiatic activity of ethanol extract of Pericampylus glaucus in male Sprague Dawley rats.

\section{EXPERIMENTAL DESIGN FOR ANTI UROLITHIATIC ACTIVITY}

The anti-urolithiatic activity of ethanol extract of Pericampylus glaucus was screened by Ethylene Glycol Induced model (Shah et al. 2012). Two dose rate (200 and $400 \mathrm{mg} / \mathrm{kg}$ (b.wt) of ethanol extract was used against ethylene glycol induced calcium oxalate stone. Ethylene glycol $0.75 \%(\mathrm{v} / \mathrm{v})$ solution in drinking water was fed to all rats groups for induction of hyperoxaluria except Group I. Animals were randomly distributed into 06 different groups comprising 05 rats in each. Group I was named 
as control that received only normal laboratory diets and drinking water throughout the study. Group II were kept as lithiatic group that received $0.75 \%(\mathrm{v} / \mathrm{v})$ ethylene glycol solution from day $1^{\text {st }}-30^{\text {th }}$. Groups III and IV were named as pretreatment groups that received $0.75 \%(\mathrm{v} / \mathrm{v})$ ethylene glycol and ethanol extract of Pericampylus glaucus at dose rate of 200 and $400 \mathrm{mg} / \mathrm{kg}$ (b.wt) daily from day $1^{\text {st }}-30^{\text {th }}$. While, groups V and VI were named as treatment groups that received $0.75 \%(\mathrm{v} / \mathrm{v})$ ethylene glycol only from day $1^{\text {st }}-14^{\text {th }}$ and from $15^{\text {th }}-30^{\text {th }}$ day along with $0.75 \%(\mathrm{v} / \mathrm{v})$ ethylene glycol received ethanol extract of Pericampylus glaucus at dose of 200 and $400 \mathrm{mg} / \mathrm{kg}$ (b.wt).

\section{EXAMINATION OF URINE FOR THE DETERMINATION OF IONIC CONCENTRATIONS}

The rats were kept individually in metabolic cages and the urine samples from each animal group was collected on day $14^{\text {th }}$ and at the end of the experiment $(24 \mathrm{~h})$ to find the magnesium and calcium ions in the urine samples. During collection of urine periods, each animal groups were allowed free access to drinking water. After diluting the urine sample with $10 \mathrm{~mL}$ of reverse osmosis water, a volume of $0.5 \mathrm{~mL}$ of urine sample was taken, acidified through $5 \mathrm{M} \mathrm{HCl}$. The acidified urine was subjected to centrifugation for $10 \mathrm{~min}$ in order to remove supernatants and debris and refrigerated at $\left(-20^{\circ} \mathrm{C}\right)$ until determination of calcium and magnesium using commercial diagnostic kits in spectrophotometer at wavelength of $422 \mathrm{~nm}$. The volume of urine sample of each treated group on day $14^{\text {th }}$ and 30 day was recorded by measuring cylinder and the $\mathrm{pH}$ was determined with $\mathrm{pH}$ meter (Kaur et al. 2009).

\section{DISSECTION OF RATS}

At the end of experiment, all animal groups after keeping on overnight fasting were sacrificed under ether anesthesia and both of kidneys were collected, immediately fixed in freshly prepared $10 \%$ buffered formalin $\mathrm{pH} 7.4$. The kidney samples were stored immediately in refrigerator (Kaur et al. 2009).

\section{PREPARATION OF SLIDES FOR HISTOPATHALOGICAL EXAMINATION}

Kidney tissues previously fixed in buffered formalin ( $\mathrm{pH7}$ 7) were bisected with the help of sterilized blades for gross examination. The tissues were further treated with $10 \%$ formalin, alcohol, xylene and finally embedded with paraffin for dehydration to fix the tissues. Microtome was used for cutting and sectioning the tissues to prepare the slides. Firstly, the slides were treated with adhesive material that was the mixture of albumin, glycerin and thymol crystals, and then previously sliced kidney tissues were allowed to stick to the glass surface. The prepared slides were then arranged on the hot plate at temperature of $65 \pm 1{ }^{\circ} \mathrm{C}$ for $10-15$ min to remove the wax materials. Dehydration was carried out by dipping the slides in $75 \%$ ethanol for $2 \mathrm{~min}$ and then washed with water for $4 \mathrm{~min}$.
Pizzolato's stain was used for the staining of calcium oxalate stones. An equal volume of $5 \%$ silver nitrate and $30 \%$ hydrogen peroxide solutions were mixed. Hydrated slides were flooded with mixture of solutions and exposed to 60 -watt tungsten-filament electric lamp. The light was kept at a distance of $15 \mathrm{~cm}$ above from the sections and an exposure time of $30 \mathrm{~min}$ was given. $30 \mathrm{~min}$ after slides were thoroughly rinsed in distilled water and counter stained with $0.1 \%$ safranin in $1 \%$ acetic acid for 3 min again rinsed in distilled water, dehydrated, cleared and finally covered with cover slip and examined microscopically for calcium oxalate stones using compound microscope Labomed (USA) (Kaur et al. 2009).

\section{BIOCHEMICAL ASSAY}

Each kidney from treated groups was taken and dried in oven at $80^{\circ} \mathrm{C}$ for a period of $24 \mathrm{~h}$. Samples of $200 \mathrm{mg}$ of the dried kidney were heated in $10 \mathrm{~mL}$ of $1 \mathrm{~N}$ HCL and homogenized. The homogenate prepared was centrifuged at $2500 \times \mathrm{g}$ for a period of $10 \mathrm{~min}$. The supernatant was separated and examined for the presence of calcium, oxalate and phosphate (Mayee \& Thosar 2011).

\section{STATISTICAL ANALYSIS}

Values were expressed as mean \pm Standard Error of Means. Values were statistically performed by one way ANOVA followed with post hoc Neumen-kelus multiple comparison tests by using Graph Pad Prism (5 version). A probability level of ${ }^{*} p<0.05$ was consider statistically significant.

\section{RESULTS AND DISCUSSION}

In present research work, male Sprague Dawley rat was used for induction of urolithiasis by administartion of $0.75 \%(\mathrm{v} / \mathrm{v})$ ethylene glycol solution that leave toxic metabolites inside the body (Tzou et al. 2016). The metabolic acidosis occurs after ingestion of ethylene glycol due to the accumulation of acid metabolite and lactate in the body as documented previously in literature (Tzou et al. 2016). Administrations of ethylene glycol for a period of 14 days lead to the formation of kidney stones that mainly composed of calcium oxalate. In this study, male animal was used due to the close resemblance of their urinary system to human and deposition of the stones in female is less as reported previously in the literature (Katzung \& Trevor 2004). The oxalate level increases with ethylene glycol due to increased availability of substrate for synthesizing oxalate enzymes (Ratkalkar \& Kleinman 2011). Increase level of calcium in the urine results crystals growth by providing an environment favorable for the nucleation and precipitation of calcium phosphate and calcium oxalate (Sathish et al. 2010).

\section{URINE $\mathrm{pH}$}

The $\mathrm{pH}$ of urine sample on $30^{\text {th }}$ day of treatment was determined by using $\mathrm{pH}$ meter. In comparison to normal 
control, a slightly acidic pH was observed in animal groups that received only ethylene glycol and treatment Pericampylus glaucus at dose rate of 200 and $400 \mathrm{mg} /$ $\mathrm{kg}$ (b.wt). However, urine $\mathrm{pH}$ was almost the same as compared to normal control. The $\mathrm{pH}$ of urine plays an important role in formation of kidney stones; dissolution of formed stones can be achieved through alteration in $\mathrm{pH}$ as previously reported in the research paper (Bahuguna et al. 2009). The acidic pH of lithiatic urine provides favorable conditions for oxalate type of kidney stone. Hence the antiurolithiatic effect of Pericampylus glaucus in pretreatment (200 and $400 \mathrm{mg} / \mathrm{kg}$ (b.wt) and treatment $200 \mathrm{mg} / \mathrm{kg}$ (b.wt) may be due to the high $\mathrm{pH}$ value as compared to lithiatic control.

\section{URINE CONCENTRATION OF ELECTROLYTES}

The urine samples from all treated animals were collected on day 14 and $30^{\text {th }}$ for the analysis of magnesium and calcium ions in spectrophotometer wavelength (422 nm). A slight significant $(p<0.05)$ enhancement in the calcium levels were seen in the urine of group II (lithiatic control and Pericampylus glaucus extract treated group at dose rate of 200 and $400 \mathrm{mg} / \mathrm{kg}$ (b.wt) on day 14 sample as compared to control. Same there was slight significant $(p<0.05)$ increase in calcium levels were also found on $30^{\text {th }}$ day of treatment in urine sample of lithiatic and treatment with Pericampylus glaucus extract at dose of $200 \mathrm{mg} / \mathrm{kg}$ (b.wt), but there was slight significant $(p<0.05)$ reduction in level of calcium was observed in $400 \mathrm{mg} / \mathrm{kg}$ (b.wt) dose treatment group as compared to lithiatic control. A slight significant $(p<0.05)$ increase in calcium level was observed in pretreatment group $(200 \mathrm{mg} / \mathrm{kg}$ (b.wt) in urine sample that was collected on $30^{\text {th }}$ day of treatment but the level was $(p<0.005)$ low as compared to normal and lithiatic group. There was no significant $(p>0.05)$ variation in calcium ion was noted in pretreatment group that received ethanolic extract at dose rate of 200 and $400 \mathrm{mg} / \mathrm{kg}$ (b.wt) as matched to normal control and variation was significant $(p<0.05)$ as compared to lithiatic group. The level of magnesium was slight significant low $(p<0.05)$, in the lithiatic and treatment group at dose of 200 and $400 \mathrm{mg} / \mathrm{kg}$ (b.wt) in the urine samples, which was collected on $14^{\text {th }}$ day of treatment as compared to control group. The reduction in magnesium levels were observed more significant $(p<0.01)$ in control (lithiatic group) and treatment $200 \mathrm{mg} / \mathrm{kg}$ dose groups on day $30^{\text {th }}$ day urine collected sample, while the concentration was significantly $(p<0.01)$ increased in pre treatment and treatment at dose $400 \mathrm{mg} / \mathrm{kg}$ (b.wt) dose group as compared to lithiatic control group (Table 1).

\section{KIDNEY WEIGHT}

There was slight significant $(p<0.05)$ increase in kidney weight were observed in lithiatic and treatment group that received ethanolic extract at dose rate of $200 \mathrm{mg} / \mathrm{kg}$ (b.wt) as compared to control. While the weight of other treated groups (pretreatment $200 \mathrm{mg} / \mathrm{kg}$ (b.wt), $400 \mathrm{mg} / \mathrm{kg}$ (b.wt) and treatment $400 \mathrm{mg} / \mathrm{kg}$ (b.wt) were remain unchanged during study (Table 2).

TABLE 1. Levels of calcium and magnesium in the urine samples collected at day 14 and 30

\begin{tabular}{|c|c|c|c|c|c|}
\hline \multirow[t]{2}{*}{ Treatment } & \multicolumn{5}{|c|}{ Concentration in day 14 sample Concentration in day 30 sample } \\
\hline & \multicolumn{5}{|c|}{$\begin{array}{l}\text { Urine pH Calcium Magnesium Calcium Magnesium } \\
\qquad(\mathrm{mg} / \mathrm{dl})(\mathrm{mg} / \mathrm{dl})(\mathrm{mg} / \mathrm{dl})(\mathrm{mg} / \mathrm{dl})\end{array}$} \\
\hline Normal control & 7.0 & $6.4 \pm 0.5$ & $3.4 \pm 0.7$ & $7.3 \pm 0.5$ & $3.4 \pm 0.5$ \\
\hline Lithiatic control & 5.8 & $13.7 \pm 0.9$ & $2.7 \pm 0.3^{* *}$ & $14.2 \pm 0.3^{* *}$ & $1.5 \pm 0.4^{* * *}$ \\
\hline Pretreatment $200 \mathrm{mg} / \mathrm{kg}$ & 6.5 & $7.5 \pm 0.6^{*}$ & $3.2 \pm 0.5^{*}$ & $9.7 \pm 0.2^{*}$ & $3.0 \pm 0.1$ * \\
\hline Pretreatment $400 \mathrm{mg} / \mathrm{kg}$ & 7.2 & $6.8 \pm 0.1^{*}$ & $3.4 \pm 0.0 *$ & $8.2 \pm 0.3^{*}$ & $3.8 \pm 0.5^{*}$ \\
\hline Treatment $200 \mathrm{mg} / \mathrm{kg}$ & 6.0 & $14.2 \pm 0^{* *}$ & $2.8 \pm 0.5^{* *}$ & $15.4 \pm 0.4^{*}$ & $2.1 \pm 0.1^{* *}$ \\
\hline Treatment $400 \mathrm{mg} / \mathrm{kg}$ & 6.8 & $13.0 \pm 0.2^{* *}$ & $3.4 \pm 0.9^{* *}$ & $9.1 \pm 0.1^{*}$ & $3.7 \pm 0.0^{*}$ \\
\hline
\end{tabular}

Data are expressed as mean concentration of ions $\pm \mathrm{SEM}, \mathrm{N}=5$, shows significant variation ${ }^{*} p<0.05$, from lithiatic control and normal control. Analysis was performed by one way of ANOVA with post hoc Neumen-kelus multiple comparison tests.

TABLE 2. Effect of ethanolic extract of Pericampylus glaucus on kidney parameters in ethylene glycol induced urolithiasis animals

\begin{tabular}{lcccc}
\hline Treatment & kidney weight $(\mathrm{g})$ & calcium $\mathrm{mg} / \mathrm{dl}$ & phosphate $\mathrm{mg} / \mathrm{dl}$ & oxalate $\mathrm{mg} / \mathrm{dl}$ \\
\hline Normal control & $0.7 \pm 0.1$ & $1.8 \pm 0.1$ & $2.2 \pm 0.6$ & $0.8 \pm 0.1$ \\
Lithiatic control & $0.8 \pm 0.1^{* *}$ & $4.4 \pm 0.2^{* *}$ & $5.6 \pm 0.1^{* *}$ & $1.9 \pm 0.5^{* * *}$ \\
Pretreatment $200 \mathrm{mg} / \mathrm{kg}(\mathrm{b} . w \mathrm{wt})$ & $0.7 \pm 0.7$ & $2.2 \pm 0.0^{* *}$ & $3.0 \pm 0.9^{* *}$ & $1.0 \pm 0.3^{* * *}$ \\
Pretreatment $400 \mathrm{mg} / \mathrm{kg}(\mathrm{b} . w \mathrm{t})$ & $0.7 \pm 0.1$ & $1.7 \pm 0.1^{*}$ & $2.4 \pm 0.1^{*}$ & $0.98 \pm 0.4^{* *}$ \\
Treatment $200 \mathrm{mg} / \mathrm{kg}$ (b.wt) & $0.8 \pm 0.1^{* *}$ & $3.4 \pm 0.5^{* *}$ & $4.9 \pm 0.1^{* *}$ & $2.0 \pm 0.8^{* * *}$ \\
Treatment $400 \mathrm{mg} / \mathrm{kg}$ (b.wt) & $0.7 \pm 0.9$ & $1.8 \pm 0.6^{*}$ & $2.6 \pm 0.8^{* *}$ & $1.0 \pm 0.0^{* *}$ \\
\hline
\end{tabular}

Data are expressed as Mean \pm SEM, shows significant $\left({ }^{*} p<0.05,{ }^{* *} p<0.01\right)$ variation as compared to lithiatic and normal control groups. Test employed was oneway ANOVA followed by Neumen-kelus test for multiple comparisons 


\section{KIDNEY HOMOGENATE ASSAY}

The kidney samples from each treated groups were homogenized and analyzed for the formation of any stone constituents. The result was compared with group I and II (control and lithiatic). A significant $(p<0.001)$ increase in calcium levels were found in animals group that received only ethylene glycol and treatment $200 \mathrm{mg} / \mathrm{kg}$ (b.wt) as compared to control. The levels of the phosphate and oxalate were slight significantly $(p<0.05)$ high in lithiatic and treatment $200 \mathrm{mg} / \mathrm{kg}$ (b.wt) dose groups. Statistically significant $(p<0.05)$ increase and decrease in phosphate and oxalate levels were also observed in pretreatment 200 and treatment $400 \mathrm{mg} / \mathrm{kg}$ (b.wt) dose groups while matched to normal and lithiatic control (Table 2). The increased levels of calcium in lithiatic and treatment 200 $\mathrm{mg} / \mathrm{kg}$ (b.wt) dose may due to lowering of glomerular filtration rate that results an obstruction in urine flow along with deposition of calcium oxalate in the urinary system and renal tubules and caused development of kidney stone (Lakshmi et al. 2014). Increased in phosphorus levels along with oxalate stress provides favorable condition for the formation of stones by forming calcium phosphate crystals that converts into calcium oxalate crystals and deposits in the renal tubules (Ratkalkar \& Kleinman 2011). Significant $(p<0.01)$ increased in urinary phosphate levels were examined in ethylene glycol induced urolithiasis animals. Increased in urinary phosphate excretion provide a suitable environment for the formation of stone by making phosphate calcium crystals and thus induced calcium oxalate deposition (Ratkalkar \& Kleinman 2011). In treatment group receiving ethanolic extract of Pericampylus glaucus at dose rate of 200 and $400 \mathrm{mg} / \mathrm{kg}$ (b.wt) decreased the urinary phosphate excretion, returning back the level of urinary phosphate to normal and hence it may be assume to be helpful in reducing the probability of stone formation. Magnesium is one of the well-known inhibitor for the formation of stone in urethra and kidney. Low level of magnesium in lithiatic and treatment 200 $\mathrm{mg} / \mathrm{kg}$ (b.wt) in ethylene glycol induced urolithic rats may provide an environment favorable for development of lithiasis. Magnesium diminished the super saturation of calcium oxalate by lessening the saturation of calcium oxalate and reduces the progression and nucleation values of calcium oxalate crystals (Touhami et al. 2007). Returning of magnesium level to normal in extract treated group indicates that it may contain certain phytochemicals that has ability for reducing super saturation of calcium oxalate by lowering the saturation of calcium oxalate (Touhami et al. 2007). Decrease level of antioxidant potential and increased lipid peroxidation in rat's kidney treated with ethylene glycol results the renal cells damage by reacting with polyunsaturated fatty acid in membranes of the cells (Bahuguna et al. 2009). Antioxidant potential and presence flavonoids, phenolic and other secondary metabolites in Pericampylus glaucus may be responsible for its antiurolithiatic action (Kifayatullah et al. 2015b).
Presence of organic and inorganic inhibitors inhibits the crystal growth such as magnesium being an inhibitor of calcium crystal prevents the growth and nucleation rate by forming complex with oxalate thus reduces oxalate super saturation in urine (Bahuguna et al. 2009). The mechinism behind suppressing high level of intracellular calcium with ethanolic extract of Pericampylus glaucus are not clear, however it may be assume due to the raised bioavailability of nitric oxide (NO), that in turns triggers cGMP (Lulat et al. 2016). Previous studies has confirmed the ability of nitric oxide (NO) donors in controlling of intracellular increase calcium levels (Lulat et al. 2016). Therefore, the plant extract of Pericampylus glaucus may possibly well decreases the level by the inhibiting oxalate or increasing the bioavailability of nitric oxide (NO) to appropriate calcium because of cGMP pathway (Pragasam et al. 2005).

\section{HISTOPATHOLOGICAL EXAMINATION}

Pizzolato's staining technique was used for kidney tissues slices stained that were examined under microscopically $(\times 40)$ for the presence of calcium oxalate stones. Irregular stones of calcium oxalate were found only in lithiatic control and treatment $200 \mathrm{mg} / \mathrm{kg}$ (b.wt) of Pericampylus glaucus extract receiving groups. There were no visible stones found in kidney tissues of other treated animals group (Figure 1). Histopathological examination of the kidney portion of ethylene glycol induced lithiasis in litiatic and $200 \mathrm{mg} / \mathrm{kg}$ (b/wt) of extract treated group showed the presence of abnormal calcium oxalate crystals while absence of visible stones formation in the kidney tissues in other treated group; this may be attributed to oxalate formation. Oral administration of ethanolic extract at different dose rate (200 and $400 \mathrm{mg}$ / $\mathrm{kg} \mathrm{b.wt)} \mathrm{decrease} \mathrm{the} \mathrm{formation} \mathrm{of} \mathrm{crystals} \mathrm{in} \mathrm{kidney} \mathrm{that}$ indicate the ability of Pericampylus glaucus to dissolve the preformed stones to some extent. Co treatment of Pericampylus glaucus extract at dose (200 and $400 \mathrm{mg} /$ $\mathrm{kg}$ b.wt) diminished the amount and mass of calcium oxalate deposits in various portions of the renal tubules. The result showed the urolithiatic protective effect of leaves of Pericampylus glaucus in ethylene glycol induced urolithiasis model. This effect of Pericampylus glaucus may be due to maintaining the balance between stone promoters and inhibitors, reducing deposition and excretion of small particles of calcium oxalate and thus reduced the chances of crystal to retain in the urinary tract (Patel et al.2016). A number of plant based drug and their phytochemicals have also shown a defensive result versus stone renal formation (Atmani et al. 2003). The result point out that dispensation of ethanolic extract of Pericampylus glaucus to the rat among ethylene glycol induced lithiasis, decreased and prevents the development of urine stones and maintains balance between stone promoters and inhibitors constituents. This may support the information concerning with antiurolithiatic activity of plant Pericampylus glaucus. 


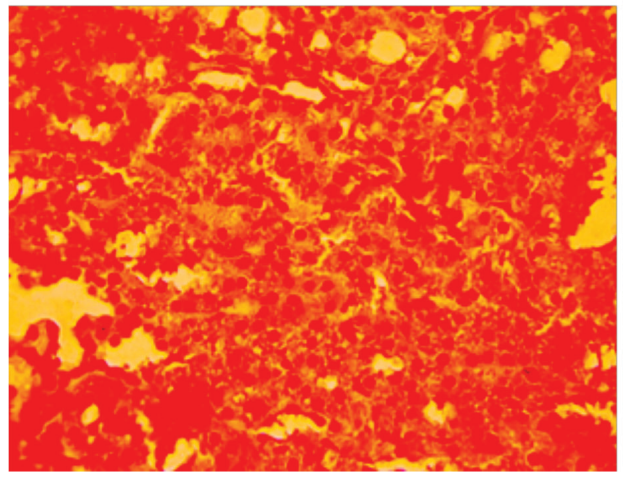

FIGURE a: (Normal control)

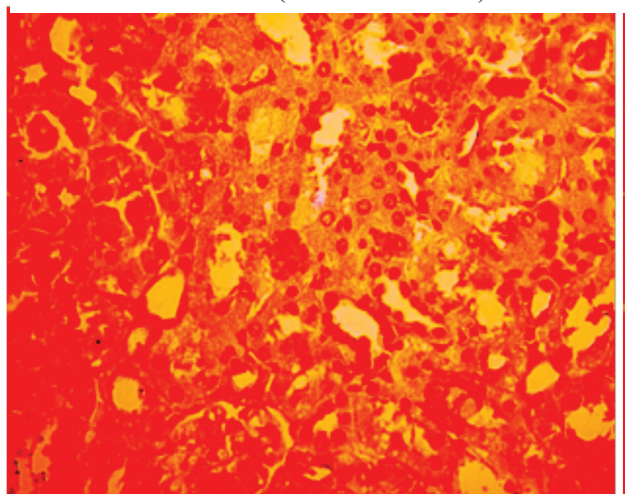

FIGURE c: (Pretreatment $200 \mathrm{mg} / \mathrm{kg}$ (b.wt)

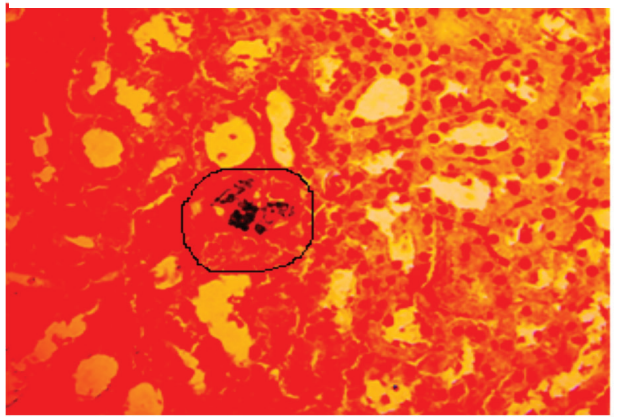

FIGURE e: (Treatment $200 \mathrm{mg} / \mathrm{kg}$ (b.wt)

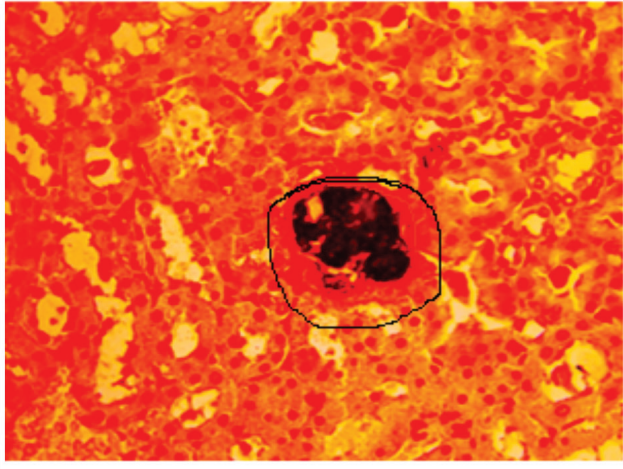

FIGURE b: (Lithiatic control)

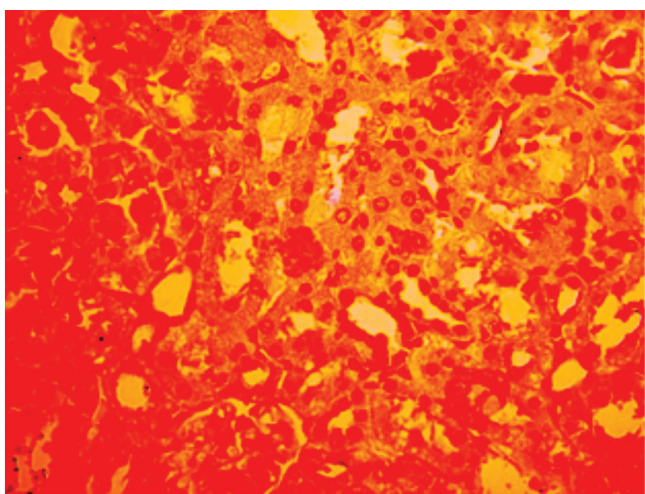

FIGURE d: (Pretreatment $400 \mathrm{mg} / \mathrm{kg}(\mathrm{b} . w \mathrm{w})$

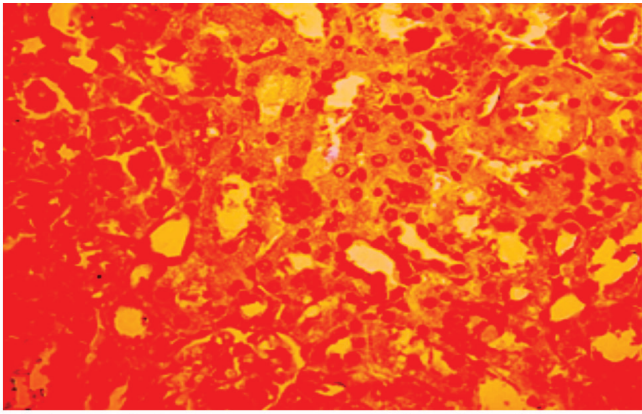

FIGURE f: (Treatment 400mg/kg (b.wt)

FIGURE 1. Examination of kidney tissue under microscope $(\times 40)$ for the presence of calcium oxalate stones.

Tissue slices stained by Pizzolato's staining technique.

\section{CONCLUSION}

This study for the first time established the antiurolithiatic effect of ethanolic Pericampylus glaucus extract against ethylene glycol induced urolithiasis and justified the traditional use of the investigated plant in the management and prevention of urinary and kidney stones. However, further studies on Pericampylus glaucus could contribute to discover a new antiurolithiatic agent. To continue this research work require the isolation of compound and evaluating the antiurolithiatic activity of the pure compound.

\section{ACKNOWLEDGEMENTS}

The authors are thankful to the Faculty of Pharmacy, Lincoln University College for providing the basic support in conducting this study and also Forest Research
Institute Malaysia for verification of the plant. The statistical analysis was carried out by Dr. Muhammad Shahid Khan.

\section{REFERENCES}

Ashok, P., Koti, B.C. \& Vishwanathswamy, A. 2010. Antiurolithiatic and antioxidant activity of Mimusops elengi on ethylene glycol-induced urolithiasis in rats. Indian Journal of Pharmacology 42(6): 380-385.

Atmani, F., Slimani, Y., Mimouni, M. \& Hacht, B. 2003. Prophylaxis of calcium oxalate stones by Herniaria hirsuta on experimentally induced nephrolithiasis in rats. BJU International 92(1): 137-140.

Awari, D.M., Vaishali, M., Babhale, S.P. \& Chaudhari, S.P. 2009. Antilithiatic effect of Achyranthus aspera Linn. leaves extract on ethylene glycol induced nephrolithiasis. Journal of Pharmacy Research 2(5): 994-997. 
Bahuguna, Y., Rawat, M., Juyal, V. \& Gnanarajan, G. 2009. Antilithiatic effect of grains of Eleusine coracana. Saudi Pharmaceutical Journal 17(2): 182-188.

Betanabhatla, K.S., Christina, B.S., Sundar, S., Selvakumar, S. \& Saravanan, S.K. 2009. Antilithiatic activity of Hibiscus sabdariffa Linn. on ethylene glycol-induced lithiasis in rats. Indian Journal of Natural Products and Resources 8(1): 43-47.

Chitme, H.R., Alok, S., Jain, S. \& Sabharwal, M. 2010. Herbal treatment for urinary stones. International Journal of Pharmaceutical Sciences and Research 1(2): 24-31.

Choubey, A., Parasar, A., Choubey, A., Iyer, D., Pawar, R. \& Patil, U. 2010. Potential of medicinal plants in kidney, gall and urinary stones. International Journal of Drug Development and Research 2(2): 431-447.

Katzung, B.G., Masters, S.B. \& Trevor, A.J. 2004. Basic \& Clinical Pharmacology. 9th edition. New York: McGrawHill Publishing Co.

Kaur, T., Bijarnia, R.K., Singla, S.K. \& Tandon, C. 2009. In vivo efficacy of Trachyspermum ammi anticalcifying protein in urolithiatic rat model. Journal of Ethnopharmacology 126(3): 459-462.

Kifayatullah, M. \& Sengupta, P. 2016. Effect of Pericampylus glaucus on plasma glucose concentration and lipid profile in streptozotocin-induced diabetic rats. Bangladesh Journal of Pharmacology 11(1): 200-205.

Kifayatullah, M., Mustapha, M.S., Sarker, M.M.R. \& Amin, M. 2017a. Effect of compounds identified in the active fraction of Pericampylus glaucus on blood glucose and lipid profiles in streptozotocin-induced diabetic rats. Egyptian Pharmaceutical Journal 16(1): 8-15.

Kifayatullah, M., Sarker, M.M.R. \& Mustapha, M.S. 2017 b. Phytochemical investigation of ethanolic extract of Pericampylus glaucus leaves from Malaysia by GC-MS analytical technique. International Journal of PharmTech Research 10: 234-240.

Kifayatullah, M., Mustafa, M.S., Sengupta, P., Sarker, M.M.R., Das, A. \& Das, S.K. 2015a. Evaluation of the acute and sub-acute toxicity of the ethanolic extract of Pericampylus glaucus (Lam.) Merr. in BALB/c mice. Journal of Acute Disease 4(4): 309-315.

Kifayatullah, M., Senguptha, P., Mustafa, M.S., Das, S.K. \& Sisugoswomi, M. 2015b. Evaluation of ethanolic extract of Pericampylus glaucus (Lamk.) Merr for total phenolic, total flavonoids contents and in vitro anti-oxidant activity. International Journal of Pharmacognosy and Phytochemical Research 7: 677-683.

Lakshmi, K.S., Prabhakaran, V., Mallikarjuna, G. \& Gowthami, A. 2014. Antilithiatic activity of Trianthema portulacastrum L. and Gymnema sylvestre $\mathrm{R}$. Br against ethylene glycol induced urolithiasis. International Journal of Pharmaceutical Sciences Review and Research 25: 16-22.

Lulat, S.I., Yadav, Y.C., Balaraman, R. \& Maheshwari, R. 2016. Antiurolithiatic effect of lithocare against ethylene glycol-induced urolithiasis in Wistar rats. Indian Journal of Pharmacology 48: 78-82.

Mayee, R. \& Thosar, A. 2011. Evaluation of Lantana camara Linn. (Verbenaceae) for antiurolithiatic and antioxidant activities in rats. International Journal of Pharmaceutical and Clinical Research 3(1): 10-14.

Pragasam, V., Kalaiselvi, P., Sumitra, K., Srinivasan, S. \& Varalakshmi, P. 2005. Counteraction of oxalate induced nitrosative stress by supplementation of 1-arginine, a potent antilithic agent. Clinica Chimica Acta 354(1-2): 159-166.

Patel, P.K., Vyas, B.A., Joshi, S.V. \& Gandhi, T.R. 2007. Evaluation of antiurolithiatic effect of pedalium murex fruit extract in ethylene glycol-induced nephrolithiasis in rat. Indian Journal of Pharmaceutical Sciences 78(2): 231-239.

Prasad, K., Sujatha, D. \& Bharathi, K. 2007. Herbal drugs in urolithiasis - A review. Pharmacognosy Reviews 1(1): 175179.

Ratkalkar, V.N. \& Kleinman, J.G. 2011. Mechanisms of stone formation. Clinical Reviews in Bone and Mineral Metabolism 9(3-4): 187-197.

Sathish, R., Natarajan, K. \& Nikhad, M.M. 2010. Effect of Hygrophila spinosa $\mathrm{T}$. anders on ethylene glycol induced urolithiasis in rats. Asian Journal of Pharmaceutical and Clinical Research 3(4): 61-63.

Shah, J.G., Patel, B.G., Patel, S.P. \& Patel, R.K. 2012. Antiurolithiatic and antioxidant activity of Hordeum vulgare seeds on ethylene glycol-induced urolithiasis in rats. Indian Journal of Pharmacology 44(6): 672-677.

Touhami, M., Laroubi, A., Elhabazi, K., Loubna, F., Zrara, I., Eljahiri, Y., Oussama, A., Grases, F. \& Chait, A. 2007. Lemon juice has protective activity in a rat urolithiasis model. $B M C$ Urology 7(1): 18-25.

Tzou, D.T., Taguchi, K., Chi, T. \& Stoller, M.L. 2016. Animal models of urinary stone disease. International Journal of Surgery 36: 596-606.

Yadav, R. \& Agarwala, M. 2011. Phytochemical analysis of some medicinal plants. Journal of Phytology 3(12): 10-14.

Yan, M.H., Cheng, P., Jiang, Z.Y., Ma, Y.B., Zhang, X.M., Zhang, F.X., Yang, L.M., Zheng, Y.T. \& Chen, J.J. 2008. Periglaucines A-D, anti-HBV and -HIV-1 alkaloids from Pericampylus glaucus. Journal of Natural Products 71(5): 760-763.

Zhao, W. \& Cui, C. 2009. Triterpenoidal constituents of Pericampylus glaucus and their antitumor activity in vitro. Chinese Journal of Medicinal Chemistry 19: 195-199.

Muhammad Kifayatullah*, Haroon Rahim, Naeem Ullah Jan \& Sudhair Abbas

Department of Pharmacy

Faculty of Life Sciences

Sarhad University of Science and Information Technology

Peshawar, Khyber-Pakhtunkhwa

Pakistan

Muhammad Shahid Khan

Department of Management Sciences

DHA Suffa University, Karachi

Pakistan

Muhammad Ikram

Department of Chemistry

Abdul Wali Khan University Mardan

Khyber-Pakhtunkhwa

Pakistan

*Corresponding author; email: kifayatpharma86@yahoo.com

Received: 6 September 2018

Accepted: 19 February 2019 